\title{
Effects of Land Use on the Riparian Vegetation along the Njoro and Kamweti Rivers, Kenya
}

\author{
Judith C. Koskey $^{1^{*}}\left(\mathbb{0}\right.$, Charles M. M'Erimba $^{2}$, George M. Ogendi ${ }^{1,3}$ \\ ${ }^{1}$ Department of Environmental Science, Egerton University, Egerton, Kenya \\ ${ }^{2}$ Department of Biological Sciences, Egerton University, Egerton, Kenya \\ ${ }^{3}$ Dryland Research Training and Ecotourism Centre, Chemeron, Egerton University, Egerton, Kenya \\ Email: *judithkoskeyc@gmail.com
}

How to cite this paper: Koskey, J.C., M'Erimba, C.M. and Ogendi, G.M (2021) Effects of Land Use on the Riparian Vegetation along the Njoro and Kamweti Rivers, Kenya. Open Journal of Ecology, 11, 807-827. https://doi.org/10.4236/oje.2021.1111049

Received: September 18, 2021

Accepted: November 12, 2021

Published: November 15, 2021

Copyright (c) 2021 by author(s) and Scientific Research Publishing Inc. This work is licensed under the Creative Commons Attribution International License (CC BY 4.0).

http://creativecommons.org/licenses/by/4.0/

\section{(c) (i) Open Access}

\begin{abstract}
Riparian zones are valuable ecosystems. They act as the ecological engineers that improve river health by delivering a range of ecosystem functions. They play a significant role in river health and provide various ecosystem goods and services for human well-being. Currently, riparian areas are under threat due to intensive human activities such as agriculture and urbanization, which alter riparian ecosystem structure and composition. The main objective of this study was to determine the effect of adjacent land use on the structure and diversity of the riparian vegetation in the Njoro and Kamweti Rivers. Along each river, three sampling sites were selected within the major land use categories which were; forest, agricultural and built-up areas. At each site, three $70 \mathrm{~m}$ long transects were established perpendicular to the river. The three plots were systematically established, separated by a $5 \mathrm{~m}$ distance along each transect. Forest canopy cover was estimated in percentage. Njoro River riparian vegetation recorded a total of 145 plant species from 40 families where trees and shrubs were dominant in the forest area, and herbs dominated the agricultural and built-up areas. In Kamweti River riparian area, a total of 110 species from 45 families were encountered, in which trees dominated the forest area. A similar trend to the Njoro River was observed, in which herbs were dominant in the agricultural and built-up areas. In Njoro River, the Shannon diversity $\left(\mathrm{H}^{\prime}\right)$ values ranged between 2.73 and 3.08 whereas Kamweti River riparian area values ranged from 2.59 to 3.40. At the level of $\mathrm{P} \leq 0.05$, T-Test revealed that there was no significant difference in plant abundance and diversity between the two rivers, with $\mathrm{F}=0.53 ; \mathrm{P}=0.51$ and $\mathrm{F}$ $=2.71 ; \mathrm{P}=0.17$. Human-centered disturbances along the Njoro and Kamweti River riparian areas have affected the riparian vegetation as shown by the decrease in plant species diversities, and the change in vegetation composition and distribution across the land uses. Due to the present and probable future
\end{abstract}


scenarios of the changes in riparian vegetation observed, there is a pressing need for an integrated approach for the management of riparian zones based on various components such as riparian condition assessment, policy framework, stakeholder's participation, management practices, legislation, and awareness.

\section{Keywords}

Land Use, Riparian Vegetation, Composition, Distribution, Diversity

\section{Introduction}

Globally, rivers are considered as the pillars of human civilization. The dependence of humans on riverine vegetation has been demonstrated by the presence of irrigated agriculture, towns, cities, and industrial sites along river banks. [1] reported that humans use more than half of the geographically accessible river runoff worldwide, therefore their significant impact particularly of an adverse kind on the structure and functioning of riparian areas would be predictable. The riverine ecosystems are considered as some of the most sensitive to human influence and potentially threatened ecosystems [2]. It has been observed that human-centered disturbances have a negative impact on the ecological security of watersheds by degrading the integrity of riverine ecosystems processes at both temporal and spatial scales. In comparison with many terrestrial and marine ecosystems, the biodiversity of river ecosystems is highly threatened or has already been diminished due to the growing need for water resources, and the impacts of climatic warming and land-use changes. The sustainability of river ecosystems stands to be further affected by increasing human threats [3].

The word "riparian" is derived from the Latin word "riparius" meaning land adjacent to the water body [4] [5]. Riparian vegetations are plant communities, occurring along the banks of water bodies and are a transition between terrestrial and aquatic systems [4] [6]. Riparian vegetations exhibit unique characteristics such as hydric soils, floral and faunal composition, and community structural relationships and provide an ideal habitat for floral and faunal communities [5] [7] [8]. A healthy riparian ecosystem is essential to the maintenance of water quality and biological integrity in surface water systems, and their destruction often leads to the degradation of adjoining aquatic ecosystems [4]. Despite their importance, anthropogenic impact on this vegetation type is still poorly understood more so in developing countries.

The natural factors that determine the composition, structure, and diversity of riparian vegetation include natural disturbances (e.g., periodic flooding or tree fall), altitudinal climate shifts geographically unique channel processes, and influences of upland on the fluvial corridor [9]. Studies demonstrate how increased human activities accompanied by the changes in land use and land cover within fluvial corridors and surrounding uplands have persistently stressed ripa- 
rian ecosystems [10] [11] [12]. Riparian degradation occurs as a result of disturbances from anthropogenic activities that occur at different levels, frequencies, and intensities exerting pressure on the riparian vegetation and biodiversity.

Healthy riparian forests are essential to the maintenance of water quality and biological integrity in surface water systems, and their destruction often leads to subsequent degradation of adjoining aquatic ecosystems [4] [13]. The establishment of agricultural fields and urban zones have been studied to cause fragmentation of the riparian vegetation thereby exposing the existing organisms to conditions of a different surrounding ecosystem [14] [15]. Between the new matrix and the remnant vegetation, alterations occur for instance, in the flow of radiation, wind, water, and nutrients what are referred to as the edge effects. These alterations bring about changes in species composition and abundance, vegetation structure and the ecological processes provided by the ecosystem [14] [16]. When significant differences exist between the surrounding matrix and the original vegetation, loss of local species of plants and animals can occur [17].

Some of the disturbances that occur as a result of land-use change that affects riparian communities include livestock grazing [18] [19], cultivation [13], hydrological modification [20]. Cultivation of crops along riparian areas causes excessive siltation and sedimentation [21] affecting the complexity and diversity of the plant species. Unregulated livestock grazing increases erosion and reduces plant vigor and alters the plant age structure and species diversity [7] [18]. However, livestock can also lead to an increase in the diversities of plant species through the transportation of seeds from distant areas and/or from the immediate riparian vegetation [22].

Njoro River is the main source of water for Lake Nakuru, a Ramsar site and an economic hub for the country since the Lake is within a National Park. Activities along with the riparian areas of this river, such as the increased rate of human and livestock population growth, unplanned settlements, increase in agricultural practices, selective cutting of riparian vegetation for charcoal, firewood, and construction is thought to have a negative impact on riparian vegetation species abundance and diversity and thus on the water quality of the river. The pressure for arable land has been on the rise within the catchment since 1994, causing a recession of forest cover and affecting the forest ecosystem integrity. Efforts have been made by various institutions and Community-Based Organizations (CBOs) to improve the overall water quality of the Njoro River since the year 2012 through the rehabilitation of the riparian areas. The extent of success of these efforts has not been well established or documented. It is against this background that this study was conceived to establish the link between adjacent land-use practices, and the riparian vegetation species composition, abundance and diversities. Kamweti River is located on the slopes of Mt. Kenya, which is a protected area by the National Park. Similar anthropogenic activities and challenges faced in the Njoro River riparian area characterize the downstream sections of Kamweti River riparian vegetation but on different levels. Therefore it will be used as a yardstick for evaluating the success of rehabilitation efforts in 
Njoro River and other related systems in the future.

An increase in human population coupled with increasing agricultural activities have been shown to affect the riparian vegetation both directly (e.g. biomass removal) and indirectly (e.g. water pollution) [13] [22] [23]. Therefore, the main objective of this study was to determine the effect of adjacent land use (forestry, agriculture, built-up areas) on the structure and diversity of the riparian vegetation in the Njoro (frequently disturbed) and Kamweti (less disturbed) Rivers. The hypothesis of the study was that anthropogenic disturbances along the Njoro River the riparian vegetation resulting from the intensive land use [18] [24] [25], will present changes in vegetation structure and diversity manifested as a lower abundance of vegetation types and fewer species.

The study of the two rivers offers an excellent study model for understanding vegetation changes associated with adjacent land uses. The extension of the geographic coverage of this type of study is also important since the structure and diversity of riparian communities are dependent upon a complex set of ecological factors (e.g., latitude and altitude) that are particular to each location and directly responsible for the diversity present in each area [4].

\section{Materials and Methods}

\subsection{Study Sites Description}

Njoro River (Figure 1(a)) is a second-order stream originating from the Eastern Mau hills (S 00³4.588'; E 03554.684'; altitude, 2887 m. Above Sea Level). Little Shuru, its main tributary, joins the river at $2293 \mathrm{~m}$ above sea level. The catchment has an area of $284 \mathrm{~km}^{2}$ with the length of the river being approximately 55 Kms discharging into Lake Nakuru (at 1750 m Above Sea Level), an internationally recognized Ramsar site. The river traverses agricultural areas, settlements, and urban areas [26]. The catchment has its rainfall peaks falling in April and August. The river is structured in a typical riffle-pool sequence [18] [27]. Pools are attractive for anthropogenic activities given that they are broad, relatively deep and are easily accessible therefore face high levels of disturbances. Disturbed pools are characterized by degraded stream banks that have little or no vegetation cover because the riparian vegetation has been heavily modified to create access to the stream for livestock watering and water abstraction for domestic use [25]. Two main vegetation types, the montane: Juniperus procera, Olea europaea ssp. Africana and sub-montane: Acacia abyssinica forest form the riparian vegetation. Canopy cover over this hydro system ranges from $0 \%$ to about 80\% [18] [27].

Kamweti River (Figure 1(b)), the reference site, is located approximately latitude $0^{\circ} 20^{\prime} \mathrm{S}$ to $0^{\circ} 22^{\prime} \mathrm{S}$ and longitude $30^{\circ} 25^{\prime} \mathrm{E}$ to $37^{\circ} 30^{\prime} \mathrm{E}$. The catchment is located on the southern slopes of Mount Kenya National Park in a well-preserved landscape consisting of rocky Afro-montane forests at higher elevations and highly diverse riverine forests in the valleys. Kamweti River is a tributary of the Thiba River [28]. The area has a cool, moist climate. The mean temperatures 


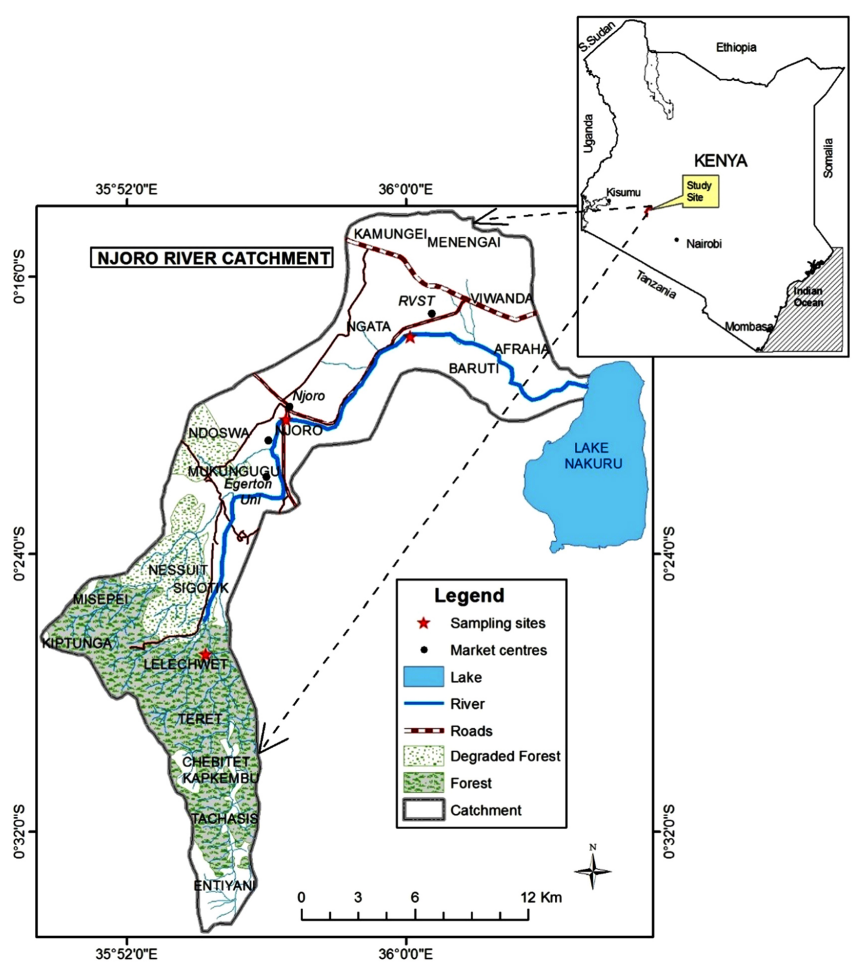

(a)

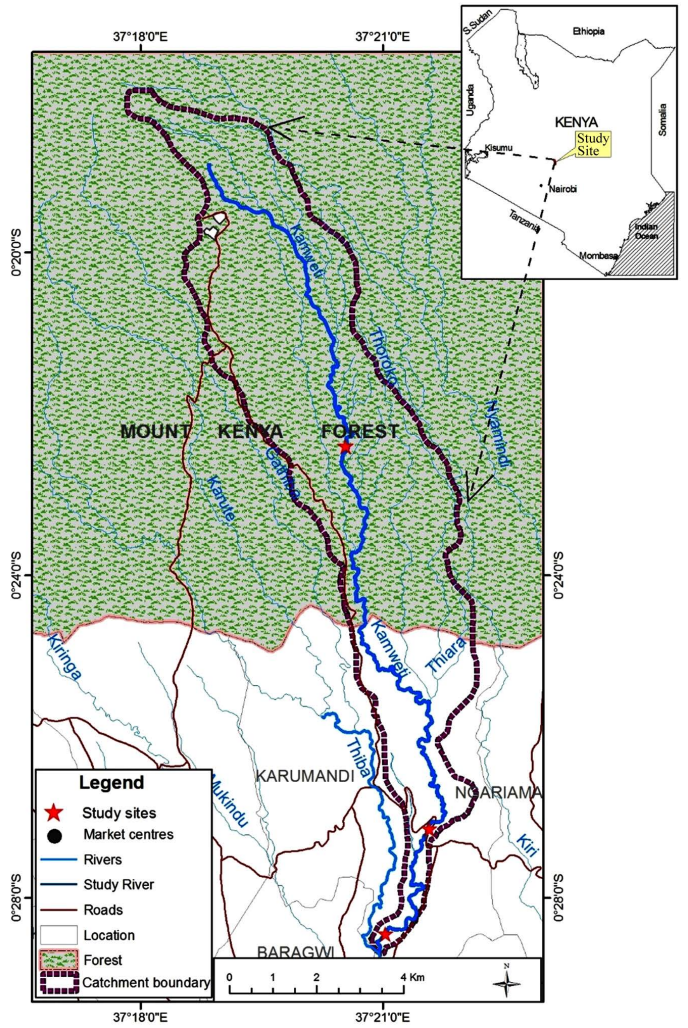

(b)

Figure 1. Maps showing the study areas (Source: Ministry of lands; survey department, 2015). (a) Njoro River Catchment; (b) Map of the Kamweti River catchment (Map of Kenya inset). 
range from $16.6^{\circ} \mathrm{C}$ in the coldest month and $20.1^{\circ} \mathrm{C}$ degrees Celsius in the warmest month. The rainfall is bimodal with two peaks, one from March to May (long rains) and the other from October to December (short rains) [29].

Upstream of the Kamweti River has been restricted to natural vegetation, under the protection of the Mt. Kenya National Park. The most predominant exotic tree species include Eucalyptus saligna and Cupressus lusitanica. Examples of indigenous tree species include Rapanea melanophloeos and some of the common shrubs include Rhus vulgaris, Vernonia auriculifera. Urtica diversifolia is one of the common under-storey naturally growing herbs in the forest. Downstream Kamweti River, the area has been cleared for cultivation and settlement. The Nyayo Tea Zone (Kenya tea zone and forest conservation) forms a buffer zone between the forest and farmers [28] [29].

\subsection{Vegetation Data Collection and Analysis}

A reconnaissance survey was first conducted to identify the various plant communities at various land uses in the Njoro and Kamweti Rivers. This plant survey was conducted after the wet season when most herbaceous species were apparent following [7]. Along each river, three sampling sites in the forest, agricultural and built-up zones were selected for this study based on the adjacent land uses. At each site, three 70-m long transects were established perpendicular to the river. The three plots were systematically established, separated by a $5-\mathrm{m}$ distance along each transect. Fewer sampling points were set in cases where sections of transects were cultivated for crops. A $10 \times 10 \mathrm{~m}$ plot was used for the sampling of trees and a plot of size $5 \times 2 \mathrm{~m}$ was used for sampling of shrubs, which were nested in the $10 \times 10 \mathrm{~m}$ plot. The grasses and herbs were sampled in smaller plots measuring $2 \times 0.5 \mathrm{~m}$, which were randomly nested in the $10 \times 10 \mathrm{~m}$ plot. All plant life-forms assessed in the subplots were combined to form a composite sample in the $10 \times 10 \mathrm{~m}$ plot. The smaller plots nested in the larger plots were established to simplify the sampling of herbs and grasses.

The size of these plots was the standardized maximum for data collection in riparian vegetation communities considering that the riparian vegetation exists as a thin plant community margin along with a river system that can intermittently expand through floodplains. The plants contained within these areas were then listed and their numbers estimated (abundance). The plants were also identified to the species level, and for those that were not easily identifiable in the field, specimens were identified using a plant specimen collection (herbarium) at Egerton University. Stream and forest canopy cover was estimated as a percentage.

\section{Data Analysis}

Data obtained from the Njoro and Kamweti River riparian areas were analyzed for plant species abundance and diversity. The plant species diversity was determined according to Shannon-Wiener Index [30]. This index considers both the 
numbers of species and their relative abundances. It will be calculated as follows;

$$
\text { Shannon Diversity Index }(H)=-\sum p_{i} \log \left(p_{i}\right) \text {. }
$$

where $p_{i}$ is the portion of $i$ th taxon and $\Sigma=$ the summation of all the values from the first to the ith taxon encountered. The Shannon diversity index ranges typically from 1.5 to 3.5 and rarely reaches 4.5 [31].

Species richness was determined by counting the number of species present. The plant species abundance and diversity between the Njoro and Kamweti riparian areas were compared by using a two-sample t-test at a 5\% significant level based on the SPSS Statistics for Windows version 26 [32].

Sorenson's Index of Similarity was measured to express the similarity between communities in the different land uses categories [33] using the formula:

$$
\text { Similarity Index }=2 Z / X+Y
$$

where $X$ is the number of species in one community, $Y$ is the number of species in another community, and $Z$ is the species common to both. The Sorenson's Index of Similarity, gives a value between 0 and 1 . The closer the value is to 1 , the more similar the communities are. Complete community overlap is equal to 1 , and 0 represents complete community dissimilarity.

\section{Results}

\subsection{Riparian Vegetation Composition and Structure across Land Use}

Three major land-use types identified in both study areas were forests, agricultural and built-up areas. A total of 145 plant species from 40 families were identified along the riparian zone of the Njoro River whereas Kamweti River riparian area, 110 plant species from 45 families were identified across the land uses. Vegetation structure and composition significantly differed across land use, particularly in the following vegetation abundance and diversity.

The forest landscape of the Njoro River majorly consisted of shrub and tree species as shown in Figure 2. Tree and shrub species dominated the landscape from the Fabaceae family such as Tipuana tipu and Crotalaria agatiflora, Oleacea family such as Olea europaea subsp. Africana, and Euphorbiaceae families such as Podocarpus latifolius which had an open canopy, and shrubs species such as Rubus steudneri and Rumex orthoneurus were also noted to be dominant. Herbs such Ipomoea spp. and Cyclosorus parasiticus and a few grass and vine species were present.

In the agricultural area, herbs such as Bidens pilosa, Galinsoga parviflora, Vernonia newii, and Ageratum conyzoides from the Asteracea family dominated the site. Herbs also from the Solanaceae family such as Solanum incanum were noted. In the area, a belt of shrubs such as Lantana trifolia, and Hypericum revolutum also existed, and grass species from the Poaceae family such as Pennisetum clandestinum and Cynodon dactylon. A few species of trees were identified which included, Syzigium cordatum, Syzigium guineense, and Dombeya torrida. The area had a percent canopy cover of $0 \%$. 


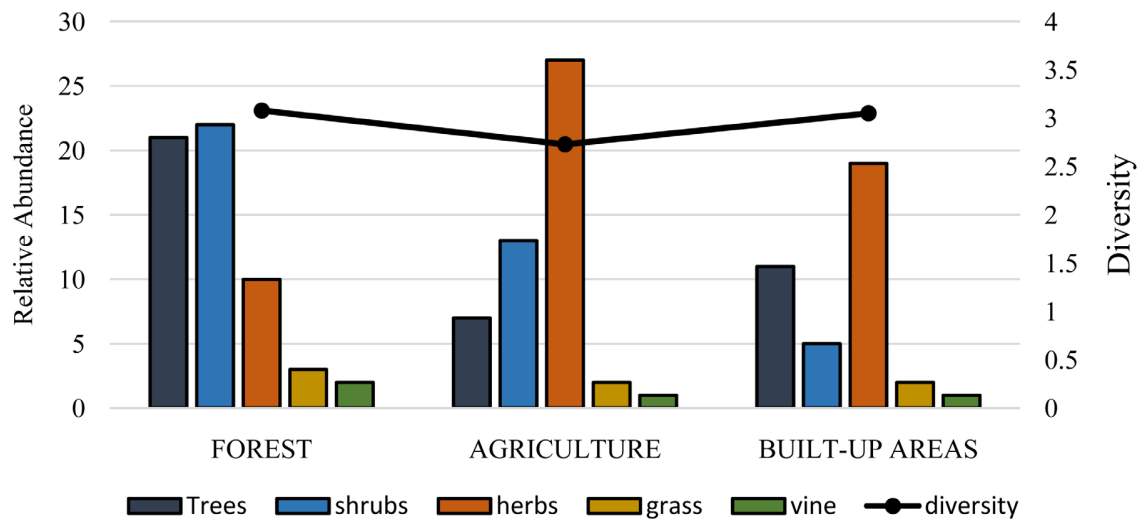

Figure 2. Riparian vegetation structure and diversity across different land uses in the Njoro River.

Similar to the agricultural area, the built-up areas were dominated by herb species the common being from the Asteraceae family such as $G$. parviflora followed by tree species from the Fabacea and Myrtaceae Families were identified. A few species of shrubs formed dense vegetation. Also, grass and vine species which were also identified.

The Kamweti River riparian vegetation structure is shown in Figure 3. The forested landscape had a 75\% canopy cover. The area was dominated by herbs followed by trees. The common herbs were from the Balsaminaceae family such as Impatiens tinctoria, Cyperaceae families such as Cyperus immensus, and Asteraceae family such as the Senecio montuosun. The common tree species included Neoboutonia macrocalyx, Cyperus denudatus, and Pennisetum purpureum which are mostly present habitats with moist conditions. Also noted in these sites were few grass species from the Poaceae family and some vines.

Similar to the forested area, the agricultural areas were dominated by herbs from the Asteracea family followed by tree species. Most of the tree species identified in this site were from the Euphorbiaceae family e.g. Croton species, Macaranga capensis, and Neoboutonia macrocalyx. Herbs in this site were mostly from the Asteraceae family. Shrubs were also present with few types of grass represented from the Poaceae family. The agricultural area had the least canopy cover of $45 \%$.

The built-up area had $60 \%$ canopy cover. Some of the tree species present were indigenous and some exotic. Similar to the agricultural area, the site was dominated by invasive species and herbs. The number of shrubs and tree species encountered was almost similar.

In Njoro River riparian zone, overall species diversity values ( $\left.\mathrm{H}^{\prime}\right)$ based on the Shannon-Weiner index were high in the forest, followed by the built-up areas and lowest in the agricultural area recording diversity values of 3.08, 3.05, and 2.73 respectively. Kamweti River riparian area recorded higher diversity values in the forest habitats (3.40) built-up areas (3.03) and lowest in the agricultural area (2.59). ANONA showed that there was no significant difference in plant 


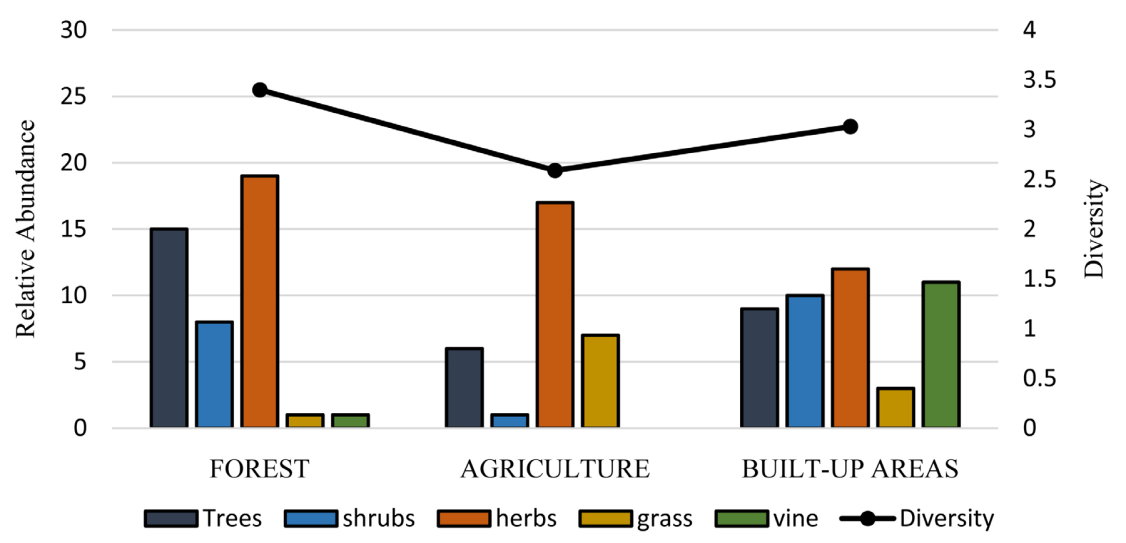

Figure 3. Riparian vegetation structure and diversity across different land uses in the Kamweti River.

abundance and diversity amongst the different land uses in the Njoro and Kamweti Rivers $\mathrm{F}=0.00 ; \mathrm{P}=1.00$ and $\mathrm{F}=0.94 ; \mathrm{P}=0.39$ respectively. T-test further revealed no significant differences in in plant abundance and diversity between the Njoro and Kamweti Rivers $\mathrm{F}=0.53 ; \mathrm{P}=0.51$ and $\mathrm{F}=2.71 ; \mathrm{P}=0.17$.

Community similarities across the different land use categories (Table 1) showed that the highest Sorenson's Index of Similarity, in Kamweti River, was found between the forest area and built-up area (0.37) and the lowest was between the forest and agricultural area (0.26). In the Njoro River, Sorenson's Index of Similarity was in the range of 0.28 and 0.34 . The highest similarity was found between the vegetation communities in the forest and the built-up areas (0.34) whereas the lowest was found between the forest and built-up area (0.28). Plant community similarities between the Njoro and Kamweti Riparian areas were highest between the built-up areas (0.29) while the forest areas and the agricultural areas recorded a similarity index of 0.24 .

\subsection{Riparian Plant Species Distribution}

The dominant vegetation species in Njoro and Kamweti Rivers riparian zones across the different land use categories identified were from the Asteraceae family. The herbs dominant from this family in the Njoro River include Ageratum conyzoides, Bidens pilosa, and Conyza floribunda. From the same family, herbs such as Bidens pilosa and Senecio vulgaris and Shrubs such as Vernonia lasiopus, Tarchonanthus camphoratus, and Gutenbergia cordifolia were identified to be common in the Kamweti River.

The Fabacea family was well present along the Njoro and Kamweti rivers. In Njoro River, the vegetation type common from the Fabacea family were mostly tree species such as Acacia abyssinica, Acacia xanthophloea, Acacia mearnsii, and Acrocarpus sp. In the Kamweti River, shrubs such as Crotalaria agatiflora and trees such as Tipuana tipu were common. Poacea family (grasses) was represented was common in both the study area in which Cynodon dactylon and Pennisetum Clandestinum were common in Njoro river and Pennisetum clandestinum and Leersia hexandra identified in the Kamweti river. 
Table 1. Sorenson's index of Similarity across different land use in the Njoro and Kamweti River riparian areas.

\begin{tabular}{ccccccc}
\hline & \multicolumn{3}{c}{ Njoro River } & \multicolumn{3}{c}{ Kamweti river } \\
\cline { 2 - 6 } & Forest & Agriculture & $\begin{array}{c}\text { Built-up } \\
\text { area }\end{array}$ & Forest & Agriculture & $\begin{array}{c}\text { Built-up } \\
\text { area }\end{array}$ \\
\hline Agriculture & 0.28 & - & - & 0.26 & - & - \\
Built-up area & 0.34 & 0.29 & - & 0.37 & 0.30 & - \\
\hline
\end{tabular}

Malvacea family was represented by trees and shrubs such as Dombeya torrida, Hibiscus diversifolius, and Hibiscus rosa-sinensis in the Njoro River whereas in Kamweti River, trees species such as Dombeya torrida and Cola greenwayi var keniensis and herbs such as Urena lobata were identified from the Malvacea family.

Euphorbiaceae was represented by tree species such as Croton megalocarpus and Ricinus communis in the Njoro River and Neoboutonia macrocalyx and Macaranga capensis in the Kamweti River which were common. Shrub species such as Plectranthus spp and herbs species such as Leonotis nepetifolia, Leucas martinicensis, were common in the Njoro River from the Lamiacea family whereas in Kamweti River, shrubs species such as Clerodendron johnstonii and Plectranthus species and herbs such as Leonotis mollissima were common.

Vegetation types that were uniquely identified in the Njoro River were from the families of Acanthaceae, Rubiaceae, Oleaceae, Hypericaceae, Verbenaceae, Rutaceae, Anacardiaceae, and Basellaceae whereas vegetation types unique to the Kamweti River were from the Balsaminaceae, Meliaceae, Apiaceae, Rosaceae, Commelinaceae, Thelypteridaceae, and Apocynaceae families.

\section{Discussion}

\subsection{Riparian Vegetation Composition and Structure across Land Use}

Plant species distribution along the rivers studied is presented in Table 2. The variation in plant species composition and distribution along the two rivers studied were a result of the differences in land uses identified. Disturbance, whether natural or anthropogenic is an important agent as it contributes to the structure and composition of plant communities in an ecosystem [7]. For both river systems, the common types of land use activities noted were forests, built up areas, and agriculture. In this study, no quantitative assessment of the disturbances caused by the land use on the riparian vegetation was done, only descriptions and effects of such disturbances are given based on actual observations.

The forest area of the Njoro River, was dominated by shrubs and trees. It was the site with least anthropogenic disturbances which included wood fuel harvesting and livestock grazing. Previous studies by Mathooko \& Kariuki [22], and reported the upper reaches of the Njoro River which this site was located was initially a dense natural montane forest with no shrubs. The anthropogenic 
Table 2. Plant species distribution along the Njoro and Kamweti Rivers.

\begin{tabular}{|c|c|c|c|c|c|c|c|}
\hline \multirow[b]{2}{*}{ No. } & \multirow[b]{2}{*}{ Family } & \multicolumn{3}{|c|}{ NJORO RIVER } & \multicolumn{3}{|c|}{ KAMWETI RIVER } \\
\hline & & Forest & Agriculture & $\begin{array}{c}\text { Built } \\
\text { up-area }\end{array}$ & Forest & Agriculture & $\begin{array}{c}\text { Built } \\
\text { up-area }\end{array}$ \\
\hline 1 & Asteraceae & + & + & + & + & + & + \\
\hline 2 & Fabaceae & + & + & + & + & + & + \\
\hline 3 & Poaceae & + & + & + & + & + & + \\
\hline 4 & Malvacea & + & + & + & + & + & + \\
\hline 5 & Lamiaceae & + & + & + & + & + & + \\
\hline 6 & Euphorbiaceae & + & + & + & + & + & + \\
\hline 7 & Cupressaceae & + & + & - & + & - & - \\
\hline 8 & Polygonaceae & + & + & + & + & + & + \\
\hline 9 & Amaranthaceae & + & + & + & + & + & + \\
\hline 10 & Solanaceae & + & + & + & + & + & + \\
\hline 11 & Balsaminaceae & - & - & - & + & + & + \\
\hline 12 & Meliaceae & - & - & - & + & + & - \\
\hline 13 & Myrtaceae & + & + & + & - & + & + \\
\hline 14 & Acanthaceae & + & + & + & - & - & - \\
\hline 15 & Rubiaceae & + & + & + & - & - & - \\
\hline 16 & Apiaceae & - & - & - & + & + & + \\
\hline 17 & Rosaceae & - & - & - & + & + & - \\
\hline 18 & Oleaceae & + & + & + & - & - & - \\
\hline 19 & Verbenaceae & + & + & - & - & - & - \\
\hline 20 & Zingiberaceae & + & + & + & + & + & + \\
\hline 21 & Commelinaceae & - & - & - & + & + & - \\
\hline 22 & Convolvulaceae & + & + & + & + & + & + \\
\hline 23 & Thelypteridaceae & - & - & - & + & + & + \\
\hline 24 & Hypericaceae & + & + & + & - & - & - \\
\hline 25 & Rutaceae & + & + & - & - & - & - \\
\hline 26 & Apocynaceae & - & - & - & + & + & - \\
\hline 27 & Anacardiaceae & + & + & - & - & - & - \\
\hline 28 & Basellaceae & + & + & + & - & - & - \\
\hline
\end{tabular}

disturbances experienced at this site might have led to the establishment of different shrub, climbers and large herbs communities [22]. In the Kamweti River riparian area, herbs were commonly followed by the trees. Tree and shrub species which were common in both study areas were from the Fabaceae, Malvaceae 
and Euphorbiacea families. Fabaceae has been found to be the most species rich family in most forest formations [34]. The species richness of these families identified in the study areas can be attributed to their good seed dispersal mechanisms which make them to be capable of colonizing different forest fragments, coupled with their ability to produce numerous seeds which eventually establish at suitable sites.

The diversity values for the forest areas of Njoro and Kamweti Rivers riparian zone, were 3.08, and 3.40, respectively. The higher species diversity in the Kamweti River riparian zone could be attributed to the protection status of the Mt. Kenya National park from human disturbances such as logging, livestock grazing and wood fuel harvesting. The undisturbed plant community structure in these sites may reflect the influence of the natural, physical and chemical environment of the plant communities present as described by [35]. Tropical forests such as the Mt. Kenya forest, are usually characterized by high species richness and diversities [36] [37]. The high species diversities in these sites are an indication that the forest has ideal habitat for floral growth and reproduction due to the weather conditions which were witnessed during the sampling periods.

[38] and [39], on the riparian structure and functions pointed out that riparian vegetation buffers sediments and nutrients from agricultural runoff, stabilizes stream banks and provides shade that minimizes evaporation and moderates stream temperatures. This was observed at forested areas of the Njoro and Kamweti riparian zones which were less disturbed anthropogenically. Also noted was that the banks at these sites were stable and favorable moist habitats were available that supported diverse plant species such as N. macrocalyx, C. Denatus and P. Purpereum which were present in these sites.

Herb species dominated the agricultural areas of Njoro Rivers riparian zones followed by the shrub species whereas in the Kamweti Rivers riparian zone, herbs and vines were dominant with few tree species. The dominance of herbs over the other growth habits in the sites could be attributed to their short life cycle that enables them to resist the instability of the ecosystem [40]. The riparian vegetation in the sites were found to be altered, with some areas having small patches of tree cover or none, which has led to severe loss of original habitat. Due to intensive cultivation to the banks of the river, the sites appeared to be more disturbed as the process entails the clearance of the original vegetation and siltation. These impact the habitat negatively and eventually lead to a decrease in plant species diversity [7].

Along with cultivation, the agricultural areas were heavily disturbed by unregulated cattle grazing and water abstraction for domestic use which has caused the left side of the bank bare, with $0 \%$ canopy cover. The trampling of soils in the banks of these sites by livestock causes siltation and sedimentation which has caused degradation making the habitat unsuitable for the establishment of riparian plants and aquatic macrophytes. Several studies, [19] [41] [42] [43] have shown that disturbance cause by livestock affects the riparian structure and 
community. [22] pointed out disturbance from livestock could lead to an increase in diversity of mud plants through transportation of seeds from distant areas and/or from the immediate riparian vegetation. This was observed along the Njoro River where rare species were also found and the introduction of different climbers and herbs due to disturbance. The regular and frequent disturbances by livestock as observed in the Njoro River may have led to the establishment of the abnormally small tree sizes which were observed along the agricultural zone.

The built up areas along the Njoro River riparian zone were dominated by herbs and trees whereas the built-up areas of the Kamweti River riparian zone were dominated by invasive species of herbs such as Lantana camara, and followed by tree species. Some of the tree species identified in the built-up areas of the Kamweti River riparian zone were indigenous species such as Vangueria madagascariensis, and Cordia abbysinica, and some of the exotic tree species identified were Eucalyptus globulus and Grevillea robusta.

Built-up areas are associated with many anthropogenic activities within and close to the riparian vegetation which has resulted in the loss of biological integrity and edge effect which can be considered an ecological factor which affects riparian vegetation [9]. The effect that arises from the transition of the built-up area and riparian vegetation is that the microclimate of the continuous habitat is affected in terms of air temperature, soil moisture and light intensity. These changes can place organisms beyond their physiological tolerance limits, affecting their ecological performance (i.e., survival, growth, or reproduction) and permanence within the ecosystem [44].

[9] also highlighted that the small sizes of the patches of riparian vegetation left as a result of land use types, generally lack an interior habitat, which causes the nucleus of the patch of vegetation to shrink. This was noted in the agricultural and built-up areas of Njoro and Kamweti River systems where some of the riparian areas where were left bare.

The diversity values recorded in agricultural and built-up areas of the Njoro River were 2.73 and 3.05 respectively whereas those of Kamweti River were 2.59 and 3.03 respectively. The areas of both rivers displayed lower diversity values due to human centered disturbances which decreased the ability of the plant species to naturally regenerate under anthropogenically constrained conditions. The riparian vegetation in the sites was found to be altered, with some areas having small patches of tree cover or none, which has led to severe loss of original habitat.

The community similarity coefficient in two riparian zones does not exhibit close relationship. The similarity coefficient of similar species recorded between forest area and agricultural area was 0.28 for the Njoro River and 0.26 for the Kamweti River, indicating that the species recorded between these two zones are less identical. Slightly higher values of similarity were recorded between the forest and built-up areas in both Njoro and Kamweti riparian zones. Local climatic 
factors and severity of biotic factors on riparian zone may have contributed to this observed similarity between these zones.

The forest areas of Njoro and Kamweti Rivers experienced intermediate disturbances both natural and human induced which contributed to high riparian plant species diversities at these sites. The notable differences in riparian plant species diversity across the different land use categories in both rivers studied can be explained based on the intermediate disturbance hypothesis (IDH) theory which points out that local species diversity is maximized when ecological disturbance is neither too rare nor too frequent. The IDH theory, explains that, at intermediate levels of disturbance, diversity is thus maximized because species that thrive at both early and late successional stages can coexist [45]. Based on the results obtained from the study, the forest areas in both riparian zones recorded high species diversities which can be interpreted based on this hypothesis. The agricultural and built-up areas of Njoro River and Kamweti River were affected by the land use at higher levels which decreased ability to naturally regenerate under anthropogenically constrained conditions, which results in low species diversity in highly disturbed sites.

\subsection{Riparian Vegetation Distribution}

In the study areas, plant species from the Asteracea family were present across the three categories of land use in the two river systems. Bidens pilosa, fastgrowing herb from the Asteracea family had a widespread distribution across the land use categories in the study areas. It behaves as a common weed of cultivated lands and pastures, but also of natural and semi-natural sites. B. pilosa, is a prolific seed producer and seeds can be easily dispersed attached to animals, birds, human clothes or by wind and water. It has also been reported as a contaminant in crop seeds and agricultural products [46]. It is regarded as a major weed in cultivated lands, forest margins, and secondary forests at elevations from sea level to $3600 \mathrm{~m}$ [46]. Ageratum conyzoides which was also common from the Asteracea family is known to be invasive in parts of Kenya, Tanzania and Uganda [47]. A. conyzoides is known to thrive in agricultural soils and is also very common in disturbed sites and degraded areas.

The Poacea family was also present in the three categories of land use in the study areas represented by species such as Cynodon dactylon, a stoloniferous grass widely naturalized in tropical and subtropical regions of the world. According to [48], the species is listed as one of the most "serious" agricultural and environmental weeds in the world. The presence of the grass species in the study areas was attributed to its ability to grow fast and that it spreads by seeds and stolons and rapidly colonizes new areas and grows forming dense mats. Studies by [49], highlighted that $C$. dactylon has the potential to alter ecosystem functions by altering fire regimes, hydrological cycles, biophysical dynamics, nutrients cycles, and community composition. The grass species is also very drought tolerant by virtue of rhizome survival through drought-induced dormancy over pe- 
riods of up to 7 months. After dormancy, it has the ability to easily re-sprout from stolons and rooted runners. Plants also recover quickly after fire and can tolerate at least several weeks of deep flooding [50]. [51] also pointed out that roots of the $C$. dactylon community effectively enhanced the stability of riparian shallow soil and riverbank.

Pennisetum clandestinum was a common species of grass encountered in the study areas. It is known to be native to the highlands of Eastern Africa but it has been widely introduced elsewhere for forage and for soil conservation [48]. In well managed situations it does not generally spread very far but it is highly tolerant of grazing and mowing and can steadily invade poorly managed plantations resulting to loss of biodiversity. L. hexandra, a semi aquatic species found in a variety of moist, usually freshwater habitats [52] was common in the Kamweti River riparian zone.

Dombeya torrida, an under-storey timber tree of wetter highland forests of East Africa and Ethiopia from the Malvacea family was common in the study area with Juniperus, Arundinaria, Hagenia, Celtis, Podocarpus and Olea capensis. Studies show that the species grows in all regions in dry, moist and wet agro-climatic zones, of 1600 - $3400 \mathrm{~m}$ [53].

Ricinus communis from the Euphobiacea family is a fast-growing shrub or small tree common in the reaches of the Njoro River. It is a highly prolific and producer of toxic seeds, very adaptable to different environments and has been widely distributed by man. It is reported invasive in many countries particularly in the tropics and since dense thickets shade out native flora it is able to have negative impacts on biodiversity. Studies by [54] [55], in the Weed risk assessments, pointed out that due to its high invasive nature, its use as the bioenergy crop has been rejected in the USA and Caribbean. Macaranga capensis and Neoboutonia macrocalyx, a sub-canopy constituent in evergreen forest, usually in wet areas and along stream banks, was common in Kamweti River riparian zone. From the Lamiacea family, the Plectranthus species which occurs in a range of habitats were present in the study areas across the different land uses. [56] reported that Plectranthus species occurs mostly in disturbed areas.

Some of the vegetation families were uniquely identified in the Njoro River such as Acanthaceae, Rubiaceae, Oleaceae, Hypericaceae, Verbenaceae, Rutaceae, Anacardiaceae, and Basellaceae whereas vegetation types unique to the Kamweti River were from the Balsaminaceae, Meliaceae, Apiaceae, Rosaceae, Commelinaceae, Thelypteridaceae, and Apocynaceae families. The species from these families occurred as a single community or in few communities. Some of the species from the families are habitat-specific and encountered in the habitat conditioned by a certain level of few ecological factors, which enabled them to grow and reproduce within a definite range of environmental conditions [57].

In the study areas, it was observed that riparian zones found next to forest areas were in better conditions, and showed higher percentage values of canopy coverage. They were also characterized by higher quantities of leaf litter and or- 
ganic matter as well as several seedlings. Such variables, according to [13], indicate a more natural condition and low anthropogenic pressure. On the contrary, it was also observed in this study that in the riparian zones adjacent to areas of agriculture, the conditions observed were bad to moderate, which were attributed to soil compaction caused by grazing and agricultural activities, this was also affirmed by [58]. [7] also pointed out that the hoof action and trampling of soils in the river bank and nearby hill slopes by livestock causes siltation and sedimentation to descend to the low plains in the channel, leaving behind a degraded habitat unsuitable for the establishment of riparian plants and aquatic macrophytes affecting species richness and diversity.

It was also observed that the zones which were adjacent to built-up areas were heavily impacted. This affirmed the previous studies which showed that urbanization is among the land uses that have more severe consequences for riparian corridors [59] [60] [61]. In this study, it was noted that, soil compaction was the main impact associated with the built-up areas in both study areas. This has been known to affect the water quality of streams [62] and the ecological functioning of riparian zones by altering their flood capacity and habitat availability [61]. Studies by [63] [64], highlighted that paving and compaction increase the proportion of impervious surfaces, which are excellent indicators of the urbanization process intensity because they may enhance the degradation of fluvial ecosystems.

\section{Conclusions}

The study confirms the variations in plant abundance, composition, and diversities along both rivers studied which are attributed to the pressures caused by the different land use categories; forests, agriculture, and built-up areas. The similarity index was low due to the shrinkage of indigenous species in the agricultural and built-up areas.

The poor riparian ecological conditions along the studied rivers in the proximity of agricultural and built areas were the case, confirming the hypothesis that intensive land uses negatively affect riparian habitat conditions. Moreover, it was clear that, as the quality of the riparian habitat increases, a greater diversity of species and structural complexity in the community was found. The forested lands showed the highest potential for preserving plant species, structure, and function complexity in riparian habitats.

The riparian vegetation plays a significant role in contributing to good stream water quality. The loss of riparian vegetation along the Njoro and downstream Kamweti Rivers, through anthropogenic activities observed such as clearing, livestock grazing, agricultural practices, and settlements, can contribute to the loss of the benefits offered by the riparian ecosystems and decrease of the overall condition of the stream. This also exerts immense pressure on the riparian vegetation leading to the decline in the typical riparian species and consequently affecting the allied biodiversity. Therefore, this study recommends further re- 
search on the physical data parameters such as the determination of the riparian zone width and sediment deposition rates which are important in studying riparian and aquatic ecosystems, and thus, the proper equipment is needed to more accurately measure these parameters.

The riparian communities can also be educated further on sustainable riparian management practices and water resource utilization through the protection (preventing human-induced alterations) and restoration (repairing of human alterations) of the riparian areas are necessary. This can be achieved under the objectives of Water Resource Users Associations which are supported by the Government of Kenya.

\section{Acknowledgements}

We acknowledge the funds provided by the Mawazo Institute to conduct the research. We are grateful to the research team that assisted us in the Njoro and Kamweti regions. We are also grateful for the assistance provided by the Departments of Environmental Science and Biological Sciences, Egerton University, in conducting this research. A special thanks also goes to the late Prof. S. T. Kariuki for his guidance and identification of vegetation species during the fieldwork.

This research is part of a $\mathrm{PhD}$ project titled Effects of land use on water quality and benthic macroinvertebrates in Kenya's Njoro and Kamweti rivers.

\section{Conflicts of Interest}

The authors declared no potential conflicts of interest with respect to the research, authorship, and/or publication of this article.

\section{References}

[1] Glenn, E.P. (2003) Riparian Areas, Functions and Strategies for ManagementNational Research Council, National Academy Press, Washington, DC. 428 pp. Environmental Science and Policy, 6, 548-549. https://doi.org/10.1016/j.envsci.2003.08.003

[2] Allan, J.D. (2004) Landscapes and Riverscapes: The Influence of Land Use on Stream Ecosystems. Annual Review of Ecology and Evolution Systems, 35, 257-284. https://doi.org/10.1146/annurev.ecolsys.35.120202.110122

[3] Shen, Y., Cao, H., Tang, M. and Deng, H. (2017) The Human Threat to River Ecosystems at the Watershed Scale: An Ecological Security Assessment of the Songhua River Basin, Northeast China. Water, 9, 219. https://doi.org/10.3390/w9030219

[4] Naiman, R.J. and Decamps, H. (1997) The Ecology of Interfaces: Riparian Zones. Annual Review of Ecology and Systematics, 28, 621-658. https://doi.org/10.1146/annurev.ecolsys.28.1.621

[5] Sunil, C., Somashekar, R. and Nagaraja, B. (2010) Riparian Vegetation Assessment of Cauvery River Basin of South India. Environmental Monitoring and Assessment, 170, 545-553. https://doi.org/10.1007/s10661-009-1256-3

[6] Tsheboeng, G. (2018) Spatial Variation of the Influence of Distance from Surface Water on Riparian Plant Communities in the Okavango Delta, Botswana. Ecological 
Processes, 7, 32. https://doi.org/10.1186/s13717-018-0140-x

[7] Mligo, C. (2017) Diversity and Distribution Pattern of Riparian Plant Species in the Wami River System, Tanzania. Journal of Plant Ecology, 10, 259-270.

https://doi.org/10.1093/jpe/rtw021

[8] Sabo, J.L., Sponseller, R., Dixon, M., Gade, K., Harms, T., Heffernan, J., Jani, A., Katz, G., Soykan, C. and Watts, J. (2005). Riparian Zones Increase Regional Species Richness by Harboring Different, Not More, Species. Ecology, 86, 56. https://doi.org/10.1890/04-0668

[9] Méndez-Toribio, M., Zermeño-Hernández, I. and Ibarra-Manríquez, G. (2014) Effect of Land Use on the Structure and Diversity of Riparian Vegetation in the Duero River Watershed in Michoacán, Mexico. Plant Ecology, 215, 285-296.

https://doi.org/10.1007/s11258-014-0297-Z

[10] Aguiar, F.C. and Ferreira, M.T. (2005) Human-Disturbed Landscapes: Effects on Composition and Integrity of Riparian Woody Vegetation in the Tagus River Basin, Portugal. Environmental Conservation, 32, 30-41. https://doi.org/10.1017/S0376892905001992

[11] Meek, C.S., Richardson, D.M. and Mucina, L. (2010) A River Runs through It: Land-Use and the Composition of Vegetation along a Riparian Corridor in the Cape Floristic Region, South Africa. Biological Conservation, 143, 156-164. https://doi.org/10.1016/j.biocon.2009.09.021

[12] Villarreal, M.L., Van Leeuwen, W.J. and Romo-Leon, J.R. (2012) Mapping and Monitoring Riparian Vegetation Distribution, Structure and Composition with Regression Tree Models and Post-Classification Change Metrics. International Journal of Remote Sensing, 33, 4266-4290. https://doi.org/10.1080/01431161.2011.644594

[13] Corbacho, C., Sánchez, J.M. and Costillo, E. (2003) Patterns of Structural Complexity and Human Disturbance of Riparian Vegetation in Agricultural Landscapes of a Mediterranean Area. Agriculture, Ecosystems \& Environment, 95, 495-507. https://doi.org/10.1016/S0167-8809(02)00218-9

[14] Murcia, C. (1995) Edge Effects in Fragmented Forests: Implications for Conservation. Trends in Ecology \& Evolution, 10, 58-62. https://doi.org/10.1016/S0169-5347(00)88977-6

[15] Šálek, L., Zahradník, D., Marušák, R., Jeřábková, L. and Merganič, J. (2013) Forest Edges in Managed Riparian Forests in the Eastern Part of the Czech Republic. Forest Ecology and Management, 305, 1-10. https://doi.org/10.1016/j.foreco.2013.05.012

[16] Dunning, J.B., Danielson, B.J. and Pulliam, H.R. (1992) Ecological Processes That Affect Populations in Complex Landscapes. Oikos, 65, 169-175. https://doi.org/10.2307/3544901

[17] Debinski, D.M. and Holt, R.D. (2000) A Survey and Overview of Habitat Fragmentation Experiments. Conservation Biology, 14, 342-355. https://doi.org/10.1046/j.1523-1739.2000.98081.x

[18] Mathooko, J.M. (2001) Disturbance of a Kenya Rift Valley Stream by the Daily Activities of Local People and Their Livestock. Hydrobiologia, 458, 131-139. https://doi.org/10.1023/A:1013160918203

[19] Roper, B.B. and Saunders, W.C. (2020) How Cattle and Wild Ungulate Use of Riparian Areas Effects Measures of Streambank Disturbance. Rangeland Ecology \& Management, 74, 32-42. https://doi.org/10.1016/j.rama.2020.08.009

[20] Shafroth, P.B., Stromberg, J.C. and Patten, D.T. (2002) Riparian Vegetation Response to Altered Disturbance and Stress Regimes. Ecological Applications, 12, 107-123. 
https://doi.org/10.1890/1051-0761(2002)012[0107:RVRTAD]2.0.CO;2

[21] Moffatt, S., McLachlan, S. and Kenkel, N. (2004) Impacts of Land Use on Riparian Forest along an Urban-Rural Gradient in Southern Manitoba. Plant Ecology, 174, 119-135. https://doi.org/10.1023/B:VEGE.0000046055.27285.fd

[22] Mathooko, J.M. and Kariuki, S.T. (2000) Disturbances and Species Distribution of the Riparian Vegetation of a Rift Valley Stream. African Journal of Ecology, 38, 123-129. https://doi.org/10.1046/j.1365-2028.2000.00225.x

[23] Atsbha, T., Desta, A.B. and Zewdu, T. (2019) Woody Species Diversity, Population Structure, and Regeneration Status in the Gra-Kahsu Natural Vegetation, Southern Tigray of Ethiopia. Heliyon, 5, e01120. https://doi.org/10.1016/j.heliyon.2019.e01120

[24] M’Erimba, C., Mathooko, J. and Ouma, K. (2014) Macroinvertebrate Distributions in Relation to Human and Animal-Induced Physical Disturbance of the Sediment Surface in Two Kenyan Tropical Rift Valley Streams. African Journal of Aquatic Science, 39, 337-346. https://doi.org/10.2989/16085914.2014.960790

[25] M'Erimba, C.M. (2019) Variation of Human and Domestic Animal's Activities with Discharge in a High-Altitude Tropical Stream, the Njoro River, Kenya. Egerton Journal of Science and Technology, 17, 50-64.

[26] Lelo, F.K., Chiuri, W. and Jenkins, M.W. (2005) Managing the River Njoro Watershed, Kenya: Conflicting Laws, Policies, and Community Priorities. Republic of South Africa (Eds), African Water Laws: Plural Legislative Frameworks for Rural Water Management in Africa, Johannesburg, South Africa.

[27] Morara, G.O., Mathooko, J.M. and Leichtfried, M. (2003) Natural Leaf Litter Transport and Retention in a Second-Order Tropical Stream: The Njoro River, Kenya. African Journal of Ecology, 41, 277-279. https://doi.org/10.1046/j.1365-2028.2003.00426.x

[28] Kaberia, D.K. (2007) Participatory Action Research and Testing the Effectiveness of Stinging Nettle as a Biopesticide in Kenya.

[29] Willkomm, M., Vierneisel, B. and Dannenberg, P. (2016) Land Use Change Dynamics in the Mt. Kenya Region-A Remotely Sensed Analysis Using RapidEye Satellite Images. Zentralblatt für Geologie und Paläontologie, 1, 23-40.

[30] Shannon, C. and Weiner, W. (1963) The Mathematical Theory of Communication. Urban University Illinois Press, Champaign, 125 p.

[31] Ifo, S.A., Moutsambote, F., Koubouana, J.M., Yoka, J., Ndzai, S.F., Bouetou-Kadilamio, L.N.O., Mampouya, H., Jourdain, C., Bocko, Y., Mantota, A.B., Mbemba, M., Mouanga-Sokath, D., Odende, R., Mondzali, L.R., Wenina, Y.E.M., Ouissika, B.C. and Joel, L.J. (2016) Tree Species Diversity, Richness, and Similarity in Intact and Degraded Forest in the Tropical Rainforest of the Congo Basin: Case of the Forest of Likouala in the Republic of Congo. International Journal of Forestry Research, 2, 1-12. https://doi.org/10.1155/2016/7593681

[32] IBM N. Corp. (2010) IBM SPSS Statistics for Windows. IBM Corp., Armonk.

[33] Sorensen, T.A. (1948) A Method of Establishing Groups of Equal Amplitude in Plant Sociology Based on Similarity of Species Content and Its Application to Analyses of the Vegetation on Danish Commons. Biologiske Skrifter, 5, 1-34.

[34] Egbe, A.M., Tabot, P.T. and Ambo, F.B. (2021) Tree Species Composition and Diversity in the Riparian Forest of Lake Barombi Kotto, Cameroon. American Journal of Plant Sciences, 12, 127-145. https://doi.org/10.4236/ajps.2021.121008

[35] Bullock, S.H., Mooney, H.A. and Medina, E. (1995) Seasonally Dry Tropical Forests. 
Cambridge University Press, Cambridge. https://doi.org/10.1017/CBO9780511753398

[36] Kindt, R., Lilleso, J. and Van Breugel, P. (2007) Comparisons between Original and Current Composition of Indigenous Tree Species around Mount Kenya. African Journal of Ecology, 45, 633. https://doi.org/10.1111/j.1365-2028.2007.00787.x

[37] Kehlenbeck, K., Kindt, R., Sinclair, F.L., Simons, A.J. and Jamnadass, R. (2011) Exotic Tree Species Displace Indigenous Ones on Farms at Intermediate Altitudes around Mount Kenya. Agroforestry Systems, 83, 133. https://doi.org/10.1007/s10457-011-9413-4

[38] Tabacchi, E., Correll, D.L., Hauer, R., Pinay, G., Planty-Tabacchi, A.M. and Wissmar, R.C. (1998) Development, Maintenance and Role of Riparian Vegetation in the River Landscape. Freshwater Biology, 40, 497-516.

https://doi.org/10.1046/j.1365-2427.1998.00381.x

[39] Riis, T., Kelly-Quinn, M., Aguiar, F.C., Manolaki, P., Bruno, D., Bejarano, M.D., Clerici, N., Fernandes, M.R., Franco, J.C. and Pettit, N. (2020) Global Overview of Ecosystem Services Provided by Riparian Vegetation. BioScience, 70, 501-514. https://doi.org/10.1093/biosci/biaa041

[40] Al-Robai, S.A., Mohamed, H.A., Howladar, S.M. and Ahmed, A.A. (2017) Vegetation Structure and Species Diversity of Wadi Turbah Zahran, Albaha Area, Southwestern Saudi Arabia. Annals of Agricultural Sciences, 62, 61-69. https://doi.org/10.1016/j.aoas.2017.04.001

[41] Kauffman, J.B. and Krueger, W.C. (1984) Livestock Impacts on Riparian Ecosystems and Streamside Management Implications... A Review. Rangeland Ecology \& anagement/ Journal of Range Management Archives, 37, 430-438. https://doi.org/10.2307/3899631

[42] Belsky, A.J., Matzke, A. and Uselman, S. (1999) Survey of Livestock Influences on Stream and Riparian Ecosystems in the Western United States. Journal of Soil and Water Conservation, 54, 419-431.

[43] Clary, W.P. and Kruse, W.H. (2004) Livestock Grazing in Riparian Areas: Environmental Impacts, Management Practices and Management Implications. In: $R i-$ parian Areas of the Southwestern United States. Hydrology, Ecology, and Management, CRC Press, Boca Raton, 237-258. https://doi.org/10.1201/9780203497753.ch11

[44] Violle, C., Navas, M., Vile, D., Kazakou, E., Fortunel, C., Hummel, I. and Garnier, E. (2007) Let the Concept of Trait Be Functional! Oikos, 116, 882-892. https://doi.org/10.1111/j.0030-1299.2007.15559.x

[45] Connell, J.H. (1978) Diversity in Tropical Rain Forests and Coral Reefs. Science, 199, 1302-1310. https://doi.org/10.1126/science.199.4335.1302

[46] Sankaran, K. and Suresh, T. (2013) Invasive Alien Plants in the Forests of Asia and the Pacific. RAP Publication, 06.

[47] Witt, A., Beale, T. and Van Wilgen, B.W. (2018) An Assessment of the Distribution and Potential Ecological Impacts of Invasive Alien Plant Species in Eastern Africa. Transactions of the Royal Society of South Africa, 73, 217-236. https://doi.org/10.1080/0035919X.2018.1529003

[48] Holm, L.G., Plucknett, D.L., Pancho, J.V. and Herberger, J.P. (1977) The World's Worst Weeds. Distribution and Biology. University Press of Hawaii, Honolulu.

[49] D’Antonio, C.M. and Vitousek, P.M. (1992) Biological Invasions by Exotic Grasses, the Grass/Fire Cycle, and Global Change. Annual Review of Ecology and Systematics, 23, 63-87. https://doi.org/10.1146/annurev.es.23.110192.000431

[50] Fernando, M. and Yakandawala, K. (2015) Performance of Selected Native Ground 
Cover Species under Induced Drought Conditions. Journal of Environmental Professionals Sri Lanka, 4, 25-35. https://doi.org/10.4038/jepsl.v4i2.7860

[51] Chen, F., Zhang, J., Zhang, M. and Wang, J. (2015) Effect of Cynodon Dactylon Community on the Conservation and Reinforcement of Riparian Shallow Soil in the Three Gorges Reservoir Area. Ecological Processes, 4, 1-8. https://doi.org/10.1186/s13717-014-0029-2

[52] Miller, S.P. and Sharitz, R. (2000) Manipulation of Flooding and Arbuscular Mycorrhiza Formation Influences Growth and Nutrition of Two Semiaquatic Grass Species. Functional Ecology, 14, 738-748. https://doi.org/10.1046/j.1365-2435.2000.00481.x

[53] Bekele-Tesemma, A. and Tengnäs, B. (2007) Useful Trees and Shrubs of Ethiopia: Identification, Propagation, and Management for 17 Agroclimatic Zones. RELMA in ICRAF Project, World Agroforestry Centre, Eastern Africa Region.

[54] Buddenhagen, C.E., Chimera, C. and Clifford, P. (2009) Assessing Biofuel Crop Invasiveness: A Case Study. PLoS ONE, 4, e5261.

https://doi.org/10.1371/journal.pone.0005261

[55] Bridgemohan, P. and Bridgemohan, R.S. (2014) Invasive Weed Risk Assessment of Three Potential Bioenergy Fuel Species. International Journal of Biodiversity and Conservation, 6, 790-796.

[56] Lukhoba, C.W., Simmonds, M.S. and Paton, A.J. (2006) Plectranthus: A Review of Ethnobotanical Uses. Journal of Ethnopharmacology, 103, 1-24.

https://doi.org/10.1016/j.jep.2005.09.011

[57] Srivastava, S. and Shukla, R. (2016) Similarity and Difference of Species among Various Plant Communities across Grassland Vegetation of North-Eastern Uttar Pradesh. Tropical Plants Research, 3, 364-369.

[58] Valero, E., Picos, J. and Álvarez, X. (2014) Characterization of Riparian Forest Quality of the Umia River for a Proposed Restoration. Ecological Engineering, 67, 216-222. https://doi.org/10.1016/j.ecoleng.2014.03.084

[59] White, M.D. and Greer, K.A. (2006) The Effects of Watershed Urbanization on the Stream Hydrology and Riparian Vegetation of Los Penasquitos Creek, California. Landscape and Urban Planning, 74, 125-138. https://doi.org/10.1016/j.landurbplan.2004.11.015

[60] Burton, M.L. and Samuelson, L.J. (2008) Influence of Urbanization on Riparian Forest Diversity and Structure in the Georgia Piedmont, US. Plant Ecology, 195, 99-115. https://doi.org/10.1007/s11258-007-9305-x

[61] Pennington, D.N., Hansel, J.R. and Gorchov, D.L. (2010) Urbanization and Riparian Forest Woody Communities: Diversity, Composition, and Structure within a Metropolitan Landscape. Biological Conservation, 143, 182-194.

https://doi.org/10.1016/j.biocon.2009.10.002

[62] Paul, M.J. and Meyer, J.L. (2001) Streams in the Urban Landscape. Annual Review of Ecology and Systematics, 32, 333-365.

https://doi.org/10.1146/annurev.ecolsys.32.081501.114040

[63] Booth, D.B. and Bledsoe, B.P. (2009) Streams and Urbanization. In: The Water Environment of Cities, Springer, Berlin, 93-123.

https://doi.org/10.1007/978-0-387-84891-4_6

[64] Díaz-Pascacio, E., Ortega-Argueta, A., Castillo-Uzcanga, M.M. and Ramírez-Marcial, N. (2018) Influence of Land Use on the Riparian Zone Condition along an UrbanRural Gradient on the Sabinal River, Mexico. Botanical Sciences, 96, 180-199. https://doi.org/10.17129/botsci.1858 